\title{
FACTORS ASSOCIATED WITH LOW BIRTH WEIGHT IN A HISTORICAL SERIES OF DELIVERIES IN CAMPINAS, BRAZIL
}

Pedro Ribeiro Coutinho ${ }^{1}$, José Guilherme Cecatti²*, Fernanda Garanhani Surita ${ }^{3}$, João Paulo de Souza ${ }^{4}$, Sirlei Siani de Morais ${ }^{5}$

Trabalho realizado no Department of Obstetrics and Gynecology, School of Medical Sciences, Universidade Estadual de Campinas - UNICAMP, Campinas, SP

\section{*Correspondência:}

R. Alexander Fleming, $n^{\circ} 101$ Campinas - SP

CEP: $13083-881$

Telefone: (19) 3521-9482 -

Fax: (19) 3521-9304

E-mail: cecatti@unicamp.br

\begin{abstract}
SUMMARY
OвJective. To identify the risk factors associated with low birth weight ( $<2500$ grams).

METHoDs. Unmatched case-control study performed in a tertiary maternity hospital in Campinas, Brazil, involving 43,499 liveborn infants delivered in the institution between 1986 and 2004. Analysis of the database containing information on deliveries of women who gave birth to infants with low $(6,477$ cases) and normal $(37,467)$ birth weight were performed. Factors associated with low birth weight were identified according to the odds ratio (OR) and $95 \%$ confidence interval $(95 \% \mathrm{Cl})$ in the bivariate analysis and according to the adjusted OR in the multivariate analysis. Sociodemographic characteristics, reproductive history, previous morbidity and factors related to current prenatal care were studied.

Results. Extremes of reproductive age, poor education, low maternal weight, smoking beyond the fourth month of pregnancy, previous cesarean section, interdelivery interval $\leq 24$ months and $\geq 37$ months, maternal history of hypertension, cardiopathy and premature delivery, few $(\leq 5)$ prenatal visits and beginning prenatal care late in pregnancy (after the 3rd month), premature rupture of membranes, increased blood pressure, infectious diseases and hemorrhages during current pregnancy were all associated with low birth weight. Maternal obesity and being a primipara were found to be protective factors.

Conclusion. These results confirm the findings of previous studies. The detection and prenatal management of modifiable factors, counseling, pre-conception intervention, adequate prenatal care and the implementation of primary and secondary prevention of maternal morbidity should be a target for all obstetrician as a potential source for reducing the incidence of low birth weight.
\end{abstract}

KEY wORDS: Birth Weight. Risk factors. Maternal welfare. Prenatal care.

\section{INTRODUCTION}

According to the World Health Organization, every newborn infant of less than 2,500 grams at birth is classified as low weight. The incidence is estimated at more than 20 million births per year. Of these, $95.6 \%$ occur in developing countries, where $16.5 \%$ of newborn infants are of low birth weight, more than twice the percentage found in developed countries (7\%). ${ }^{1}$

Low birth weight is the result of two obstetrical situations: premature delivery 1,2 and/or a pregnancy in which the fetus has intrauterine growth restriction ${ }^{3}$ attributed to poor uteroplacental perfusion ${ }^{4}$. Preterm and low birth weight are the main determining factors of adverse outcomes in childhood and are associated with poorer indicators of child morbidity ${ }^{1}$ and mortality ${ }^{5}$. The reduction in the incidence of low birth weight by one-third between 2000 and 2010 with the objective of reducing child mortality is one of the Millennium Development Goals established by the World Health Organization and proposed in 2005 in their "Declaration and Recommendations for Action" 1.

Over the last 30 years, there has been an improvement in the survival rates of low birth weight infants in developed nations ${ }^{3}$. Nonetheless, in global terms, children born with low birth weight are 20 -fold more likely to die prematurely compared to infants of normal birth weight ${ }^{6}$. Likewise, these children experience more morbidity, both in the short and long term. Among these, the principal morbidities include respiratory distress syndrome, necrotizing enterocolitis, amaurosis, deafness, hydrocephaly, mental retardation and cerebral palsy ${ }^{1}$. Children with a birth weight below 2,500 grams have a greater chance of developing attention deficit hyperactive disorder compared to children of normal birth weight ${ }^{7}$. There is also a greater vulnerability to infectious diseases due to a poorer immune response ${ }^{8}$. Even certain conditions in adulthood may be associated with low birth weight, such as

1. Mestre em Tocoginecologia - Médico contratado do CAISM da Universidade Estadual de Campinas - UNICAMP, Campinas,SP

2. Professor Titular de Obstetricia da Universidade Estadual de Campinas - UNICAMP, Campinas,SP

3. Doutora em Tocoginecologia - Professora Assistente Doutora de Obstetrícia do Departamento de Tocoginecologia da Universidade Estadual de Campinas UNICAMP, Campinas,SP

4. Mestre em Tocoginecologia - Médico contratado do CAISM da Universidade Estadual de Campinas - UNICAMP, Campinas, SP

5. Mestre em Estatística do Departamento de Tocoginecologia da Universidade Estadual de Campinas - UNICAMP, Campinas,SP 
coronary disease, cerebral vascular accident, hypertension, type 2 diabetes $^{9}$, insulin resistance ${ }^{10}$ and depression ${ }^{11}$.

Therefore, it is clear that low birth weight represents a heavy burden for healthcare services worldwide. In poorer countries where fewer resources are destined for healthcare, the direct, indirect, immediate and later repercussions of low birth weight constitute a relevant public health issue ${ }^{1}$. However, the great majority of scientific evidence accumulated on this subject is generated in developed countries. Therefore, this study was carried out in a referral maternity hospital in a developing country with the objective of identifying risk factors associated with low birth weight.

\section{Methods}

This is an unmatched case-control study carried out at the Center for Woman's Integral Healthcare (CAISM), a tertiary, referral maternity hospital that covers a region of 3 million inhabitants of the city of Campinas in the state of São Paulo, Brazil. A specific database is systematically and prospectively fed with information on obstetrical hospitalizations occurring in the institution, including demographic data and maternal history, reproductive history, prenatal care, delivery, the puerperium and information on the perinatal period. These data are originally collected on forms filled out by the attending physicians from the admission of the patient until her release from hospital. The data are then checked and revised as necessary by a medical supervisor and then entered into the database by technical staff.

The 52,136 records of all deliveries carried out in the institution between January 1986 and December 2004 were originally available for this study. Based on these records, a second database was built in which only those records with information on birth weight were included, excluding the records of infants delivered with a weight of less than 500 grams or more than 4,000 grams at birth, those who were stillborn and twin births. A total of 8,192 records were excluded. The macrosomic newborn infants (those with a birth weight of over 4,000 grams) were excluded because they have specific profiles of maternal and perinatal morbidity and mortality that are different from those of newborn infants with a birth weight that is considered normal ${ }^{12}$. This selection resulted in a database of 43,944 records.

The records were then divided into two groups: 1) Newborn infants with low birth weight (cases), consisting of those whose weight at birth was less than 2,500 grams $(6,477$ cases; $14.7 \%$ of the total population studied and $12.8 \%$ of the liveborn infants); and 2) Newborn infants of normal weight (controls), those whose weight at birth ranged from 2,500 to 3,999 grams (37,467 cases; $85.2 \%$ of the total population studied and $87.2 \%$ of the total number of liveborn infants). Since it was possible to study all these cases, thereby avoiding any selection bias either for cases or controls, this entire sample was evaluated. With respect to the selection of controls, the proportion of almost 6 controls for each case eliminated the need to perform matching or counterbalancing procedures. Due to the incorrectness of available data regarding estimation of gestational age it was not possible to differentiate low birth weight cases between preterm or small for gestational age babies.

The following variables were considered independent: the sociodemographic characteristics of the mother/lifestyle habits (age, marital status, education level, pre-gestational body mass index, smoking habits), obstetrical history (number of pregnancies including the current one, parity, number of cesarean sections, abortions, stillbirths, living children, interval since previous delivery); history of maternal morbidity (cardiopathy, urinary tract infection, chronic hypertension and others, including tuberculosis, syphilis, diabetes, bone sequelae in the pelvis/lower limbs, abdominal surgery), obstetrical history (preeclampsia, preterm delivery and others, including hemorrhage during pregnancy, postpartum hemorrhage, prolonged pregnancy, congenital malformations, puerperal infection, polyhydramnios), factors related to current prenatal care (total number of visits, time when prenatal care was initiated) and complications during current pregnancy (course of blood pressure, infectious diseases, hemorrhages, surgeries during pregnancy, premature rupture of membranes).

Of all the eligible records available in the database, a proportion was excluded from the statistical analysis for each variable due to missing information. These proportions were different for each variable and cannot be considered a selection bias since they did not constitute a subsample with different characteristics from those of the population studied.

Initially, a bivariate analysis was carried out using the Epi Info software program, version 6.04b, in which each independent variable was crossed with the variable represented by the weight of the newborn infant. The possible risk factors were comparatively evaluated between cases (low birth weight) and controls (normal birth weight) and the odds ratio (OR) and $95 \%$ confidence interval $(95 \% \mathrm{Cl})$ were calculated. For ordinal variables with a tendency to increase or decrease linearly in risk, the $x^{2}$ for linear trends was calculated. To identify the factors and complications independently associated with low birth weight, multiple regression analysis was performed using the SAS software package, version 9.02. For this analysis, the stepwise method for regression models was used, considering low birth weight as the dependent variable and all the other predictor variables used as potential confounding factors for the adjustment of the respective odds ratios. The protocol of this study was approved by the Institutional Review Board prior to initiation.

\section{RESULTS}

With respect to the mean age of the mothers in this study, there was no statistically significant difference between cases (25.6 \pm 7 years) and controls ( $25.4 \pm 6.5$ years). Bivariate analysis of the demographic variables found that young women of 10-19 years of age and adults over 30 years of age, as well as women without a partner, with lower education levels, with low maternal weight prior to pregnancy and smoking beyond the fourth month of pregnancy had a greater risk of giving birth to low birth weight infants. The risk of low birth weight is higher for women who are pregnant for the first time, with no living children, with an interdelivery interval $\leq 24$ months or $\geq 37$ months or who have not previously delivered and also for those who have had several pregnancies, with previous abortions and stillbirths (Table 1).

Women with a history of chronic hypertension, cardiopathies, preeclampsia or preterm delivery were found to have an increased risk of delivering an infant with low birth weight, as well as those who had received no prenatal care or who had attended fewer than five prenatal visits, who had hypertension (either chronic or gestational), infections, hemorrhages, premature rupture of membranes, or who were submitted to conization, cerclage or other surgeries during pregnancy (Table 2). 


\begin{tabular}{|c|c|c|c|}
\hline CHARACTERISTICS & Cases n (\%) & Controls n (\%) & OR $(95 \% \mathrm{Cl})$ \\
\hline \multicolumn{4}{|l|}{ Age (years) } \\
\hline $\begin{array}{l}10-19 \\
20-29\end{array}$ & $\begin{array}{l}1,427(22.0) \\
3,002(46.3)\end{array}$ & $\begin{array}{c}7,729(20.6) \\
18,861(50.3)\end{array}$ & $1.16(1.08-1.24)$ \\
\hline $30-39$ & $1,631(25.2)$ & $8,906(23.8)$ & $1.15(1.08-1.23)$ \\
\hline$>40$ & $204(3.1)$ & $852(2.3)$ & $1.5(1.28-1.77)$ \\
\hline Unknown & $213(3.3)$ & $1119(2.9)$ & \\
\hline \multicolumn{4}{|l|}{ Marital status } \\
\hline With a partner & $4,676(72.2)$ & $28,700(76.6)$ & 1 \\
\hline Without a partner & 1,321 (20.4) & 7,237 (19.4) & $1.12(1.05-1.20)$ \\
\hline \multicolumn{4}{|l|}{ Education level (in years of schooling) * } \\
\hline 0 & $269(4.2)$ & $1,522(4.1)$ & $1.35(1.13-1.62)$ \\
\hline $1-7$ & 3,103 (47.9) & $19,204(51.3)$ & $1.24(1.09-1.4)$ \\
\hline $8-11$ & $852(13.2)$ & $6,019(16.1)$ & $1.08(0.94-1.24)$ \\
\hline$>12$ & $321(5.0)$ & $2,456(6.6)$ & \\
\hline \multirow{2}{*}{\multicolumn{4}{|c|}{ BMI }} \\
\hline & & & \\
\hline Underweight (<19.8) & $1,617(24.9)$ & $7,653(20.4)$ & $1.63(1.52-1.75)$ \\
\hline Normal (19.8 - 26.0) & $2,099(32.4)$ & $16,219(43.3)$ & $\left.\frac{1}{2} 106\right)$ \\
\hline Uverwelght $(20.1-29.0)$ & $345(5.3)$ & $2,835(7.5)$ & $0.94(0.83-1.06)$ \\
\hline Unknown & $2,069(31.9)$ & $8.078(21.5)$ & \\
\hline \multicolumn{4}{|l|}{ Smoking Habit } \\
\hline Never smoked & $3,098(47.8)$ & $21,567(57.6)$ & 1 \\
\hline Not during pregnancy & $321(5.0)$ & $2.382(6.4)$ & $0.94(0.83-1.06)$ \\
\hline Up to the 4 th month ( $\leq 10 \mathrm{cig} /$ day $)$ & $102(1.6)$ & $585(1.6)$ & $1.21(0.97-1.51)$ \\
\hline Up to the 4 th month $(>10 \mathrm{cig} /$ day $)$ & $28(0.4)$ & $199(0.5)$ & $0.98(0.64-1.48)$ \\
\hline Beyond the 4th month ( $\leq 10 \mathrm{cig} /$ day $)$ & $561(8.7)$ & $2.554(6.8)$ & $1.53(1.38-1.69)$ \\
\hline Beyond the 4th month (>10 cig/day) & $275(4.2)$ & $1.179(3.1)$ & $1.62(1.41-1.87)$ \\
\hline Unknown & $2,092(32.3)$ & $9,001(24.0)$ & \\
\hline \multirow{2}{*}{\multicolumn{4}{|c|}{$\begin{array}{l}\text { OBSTETRICAL HISTORY } \\
\text { Number of pregnancies }\end{array}$}} \\
\hline & & & \\
\hline 1 & $2,321(35.8)$ & $12,235(32.6)$ & $1.24(1.15-1.33)$ \\
\hline 2 & $1,283(19.8)$ & $8,376(22.3)$ & 1 \\
\hline $\begin{array}{l}3-5 \\
\geq 6\end{array}$ & 2,025 (31.2) & $12,581(33.6)$ & $1.05(0.97-1.13)$ \\
\hline Unknown & $135(2.1)$ & $\begin{array}{l}3,596(9.6) \\
679(1.8)\end{array}$ & $1.29(1.1 /-1.43)$ \\
\hline $\begin{array}{l}\text { Parity } \\
0\end{array}$ & $2301(355)$ & $11713(313)$ & $130(1.21-1.40)$ \\
\hline 1 & $1,325(20.4)$ & $8,798(23.5)$ & 1 \\
\hline $2-4$ & $1,860(28.7)$ & $11,498(30.7)$ & $1.07(1.0-1.16)$ \\
\hline$\geq 5$ & $454(7.0)$ & $2,470(6.6)$ & $1.22(1.09-1.37)$ \\
\hline Unknown & $537(8.3)$ & $2,988(7.9)$ & \\
\hline \multicolumn{4}{|l|}{ Number of cesarean sections } \\
\hline 0 & $4,286(66.2)$ & 24,894 (66.4) & 1 \\
\hline 1 & $946(14.6)$ & $5,435(14.5)$ & $1.01(0.94-1.09)$ \\
\hline 2 & $357(5.5)$ & $2,000(5.3)$ & $1.04(0.92-1.17)$ \\
\hline$\geq 3$ & $189(2.9)$ & $945(2.5)$ & $1.16(0.99-1.37)$ \\
\hline Unknown & 699 (10.8) & 4,193 (11.2) & \\
\hline \multicolumn{4}{|l|}{ Number of abortions * } \\
\hline 0 & $4,324(66.7)$ & $25,737(68.7)$ & 1 \\
\hline 1 & $961(14.8)$ & $5,313(14.2)$ & $1.08(1.0-1.16)$ \\
\hline 2 & $283(4.4)$ & $1,326(3.5)$ & $1.27(1.11-1.45)$ \\
\hline$\geq 3$ & $180(2.8)$ & $686(1.8)$ & $1.56(1.32-1.85)$ \\
\hline \multirow{2}{*}{\multicolumn{4}{|c|}{ Stillbirths * }} \\
\hline & & & \\
\hline 0 & 5,209 (80.4) & $30,966(82.6)$ & 1 \\
\hline 1 & $309(4.8)$ & $1.110(3.0)$ & $1.65(1.45-1.89)$ \\
\hline 2 & $73(1.1)$ & $141(0.4)$ & $3.08(2.29-4.13)$ \\
\hline$\geq 3$ & $27(0.5)$ & $54(0.1)$ & $2.97(1.82-4.83)$ \\
\hline \multirow{2}{*}{\multicolumn{4}{|c|}{ Living children }} \\
\hline & & & \\
\hline 0 & $2,508(38.7)$ & $12,032(33.1)$ & $1.39(1.31-1.47)$ \\
\hline $1-3$ & $2,791(43.1)$ & $18,590(49.6)$ & 1 \\
\hline $\begin{array}{r}4-8 \\
-9\end{array}$ & $596(9.2)$ & $3,623(9.6)$ & $1.10(0.99-1.21)$ \\
\hline $\begin{array}{l}\geq 9 \\
\text { Unknown }\end{array}$ & $\begin{array}{c}26(0.4) \\
556(85)\end{array}$ & $173(0.5)$ & $1.0(0.65-1.54)$ \\
\hline \multicolumn{4}{|l|}{$\begin{array}{l}\text { Unknown } \\
\text { Interdelivery interval (in months) }\end{array}$} \\
\hline None (primiparas) & $2,314(35.7)$ & $11,594(30.9)$ & $1.75(1.57-1.94)$ \\
\hline$\leq 12$ & $284(4.4)$ & $1,221(3.2)$ & $2.03(1.73-2.39)$ \\
\hline $13-24$ & 790 (12.2) & $5,430(14.5)$ & $1.27(1.13-1.44)$ \\
\hline $\begin{array}{l}25-36 \\
\geq 37\end{array}$ & $\begin{array}{c}481(7.4) \\
399(216)\end{array}$ & $\begin{array}{l}4,205(11.2) \\
9674(25.8)\end{array}$ & $126(13-141)$ \\
\hline Unknown & $\begin{array}{l}1,399(21.6) \\
1,209(18.6)\end{array}$ & $\begin{array}{l}9,6 / 4(25.8) \\
5,343(14.2)\end{array}$ & \\
\hline Total & 6,477 & 37,467 & \\
\hline
\end{tabular}

* $\times 2$ linear trend $p<0.00001$ 
FACTORS ASSOCIATED WITH LOW BIRTH WEIGHT IN A HISTORICAL SERIES OF DELIVERIES IN CAMPINAS, BRAZIL

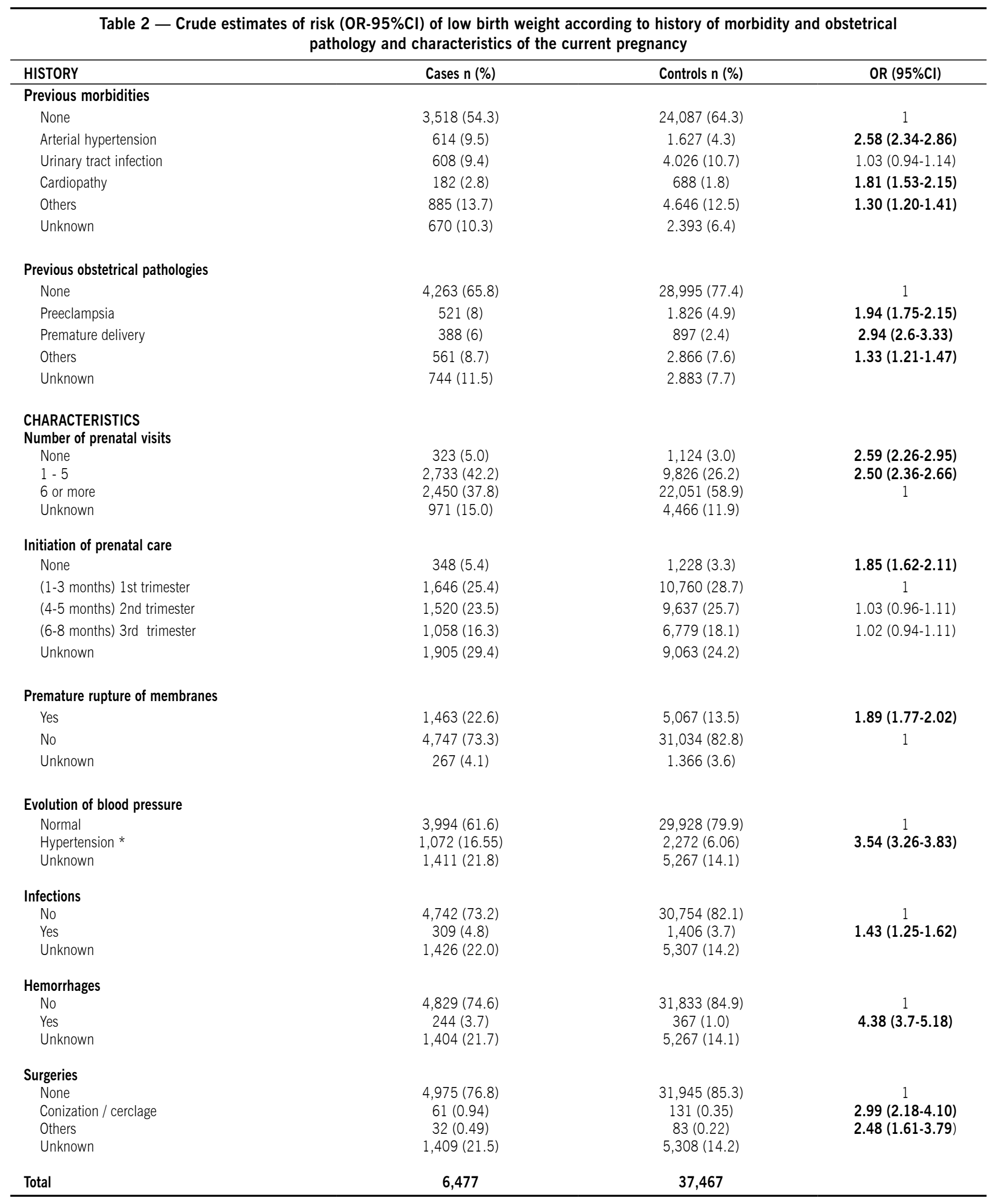

* Systemic arterial hypertension/ Preeclampsia 
According to the multiple regression analysis, age, low educational level, low maternal weight and smoking beyond the fourth month of pregnancy were risk factors for low birth weight. Maternal obesity was found to be a protective factor. Parity and marital status were not independently associated with this outcome. Unlike the bivariate analysis, logistic regression found that there is a protective effect in primiparas and that women with a history of cesarean sections have an increased risk of giving birth to infants with a birth weight of less than 2,500 grams. Confirming the preliminary analyses, women with no living children also have an increased risk of having an infant with low birth weight. With respect to the interval between deliveries, both extremes ( $\leq 24$ months and $\geq 37$ months) were associated with the occurrence of low birth weight. History of previous abortions or stillbirths was not identified as independent factors associated with low birth weight in this population. Maternal history of chronic hypertension, cardiopathy and preterm delivery were risk factors, whereas a history of preeclampsia was not. Having attended fewer than 5 prenatal visits was found to be a risk factor independently associated with the birth of an infant with low birth weight, as well as beginning prenatal care late (after the third month of pregnancy). Finally, the occurrence of premature rupture of membranes, increased blood pressure, infectious diseases and hemorrhages during the current pregnancy were found to be factors significantly associated with low birth weight (Table 3 ).

\begin{tabular}{|c|c|c|c|}
\hline \multirow{2}{*}{$\begin{array}{l}\text { Associated Factors } \\
\text { Age (continuous variable) }\end{array}$} & \multirow{2}{*}{$\frac{\text { ORadj }}{1.01}$} & \multicolumn{2}{|c|}{$95 \% \mathrm{Cl}$} \\
\hline & & 1.00 & -1.02 \\
\hline \multicolumn{4}{|l|}{ BMI } \\
\hline Underweight $(<19.8)$ & 1.72 & 1.52 & - 1.93 \\
\hline Overweight (26.1 a 29.0) & 0.93 & 0.76 & -1.13 \\
\hline Obesity (> 29.0) & 0.73 & 0.58 & -0.91 \\
\hline Low education level ( $0-7$ years of schooling) & 1.29 & 1.13 & - 1.47 \\
\hline Smoking beyond the 4 th month of pregnancy & 1.51 & 1.32 & - 1.72 \\
\hline \multicolumn{4}{|l|}{ Number of pregnancies } \\
\hline First & 0.72 & 0.56 & -0.91 \\
\hline$\geq 3$ & 0.97 & 0.82 & -1.15 \\
\hline Previous cesarean sections & 1.21 & 1.04 & -1.40 \\
\hline \multicolumn{4}{|l|}{ Number of living children } \\
\hline None & 2.22 & 1.65 & - 3.00 \\
\hline$\geq 4$ & 0.82 & 0.67 & - 1.01 \\
\hline \multicolumn{4}{|l|}{ Interdelivery interval } \\
\hline None (primiparas) & 1.33 & 0.91 & -1.95 \\
\hline 1 -12 months & 1.88 & 1.37 & - 2.57 \\
\hline 13 - 24 months & 1.21 & 0.97 & -1.50 \\
\hline$\geq 37$ months & 1.35 & 1.10 & - 1.65 \\
\hline \multicolumn{4}{|l|}{ Previous morbidities } \\
\hline Systemic Arterial Hypertension & 1.74 & 1.38 & - 2.18 \\
\hline Urinary tract infection & 1.08 & 0.91 & -1.29 \\
\hline Cardiopathy & 2.21 & 1.64 & -2.99 \\
\hline Others & 1.21 & 1.03 & -1.42 \\
\hline \multicolumn{4}{|l|}{ Obstetrical history } \\
\hline Preeclampsia & 1.13 & 0.90 & -1.43 \\
\hline Previous premature delivery & 2.36 & 1.84 & - 3.03 \\
\hline Others & 1.29 & 1.06 & - 1.58 \\
\hline \multicolumn{4}{|l|}{ Prenatal care } \\
\hline Few prenatal consultations $(0-5)$ & 2.61 & 2.32 & -2.94 \\
\hline Late start of prenatal care (after 3rd month) & 1.22 & 1.14 & - 1.46 \\
\hline No prenatal care & 1.06 & 0.84 & -1.35 \\
\hline \multicolumn{4}{|l|}{ Data from present pregnancy } \\
\hline Premature rupture of membranes & 1.97 & 1.74 & -2.23 \\
\hline High blood pressure & 2.82 & 2.40 & - 3.32 \\
\hline Infectious diseases in pregnancy & 1.28 & 1.03 & - 1.59 \\
\hline Prepartum hemorrhages & 3.81 & 2.79 & - 5.18 \\
\hline
\end{tabular}




\section{Discussion}

In this study, various factors associated with low birth weight were identified in a developing country population with an elevated prevalence of high risk pregnancies, and these results are in agreement with data published in the literature with respect to various risk factors for low birth weight.

Extremes of reproductive age ${ }^{13,14}$, women without a partner ${ }^{14}$, low educational level and low pregestational BMI ${ }^{1,15,16}$ were findings shown to be risk factors for low birth weight in this population, and these findings are in agreement with data reported by various other investigators. On the other hand, the present study also showed obesity to be a protective factor, which may reflect the fact that obese women have a greater risk of developing hyperglycemic states or diabetes (gestational or type II), commonly associated with a greater gain in fetal weight. Smoking beyond the $4^{\text {th }}$ month of pregnancy was shown to be a risk factor irrespective of the number of cigarettes smoked per day, and this finding is in agreement with reports from previous studies ${ }^{17-20}$.

There is evidence that pregnant women who suffer from chronic psychosocial stress ${ }^{21}$, who have ambivalent feelings with respect to the pregnancy ${ }^{22}$, or who have suffered some form of psychological, physical and/or sexual violence during pregnancy ${ }^{23}$ have a greater chance of giving birth to an infant with a birth weight of less than 2,500 grams. Although these factors were not evaluated in this population of pregnant women, systematic incorporation of these forms of evaluation in routine prenatal care represents a challenge, particularly in less developed regions where these factors may contribute significantly towards the occurrence of low birth weight.

Parity was not found to be an independent risk factor for low birth weight, despite the fact that the bivariate analysis showed it to be so, and this is in agreement with data published in the literature. These results show that women with a history of abortions and stillbirths have a greater chance of having infants with low birth weight, this risk increasing as the number of these previous obstetrical outcomes also increases. One possible explanation for this may be the association between these outcomes and morbidities that affect placental vasculature, such as collagenosis and antiphospholipid syndrome, which are also associated with low birth weight. Nevertheless, none of these characteristics remained significantly associated with low birth weight in the multivariate analysis, possibly because they are simultaneously associated with some of the other characteristics identified. As in previous studies ${ }^{24,25}$, short or long interdelivery intervals were associated with low birth weight. In addition, previous cesarean sections were associated with a $20 \%$ increase in the occurrence of low birth weight. As well as the tendency of pregnancies with lower gestational ages to result in repeat cesarean sections, it is probable that some of the situations of risk for low birth weight also contributed towards increasing indications for cesarean sections.

In agreement with the findings of Graham et al ${ }^{26}$, the results of the current study show that chronic maternal morbidities such as hypertension and cardiopathy were positively associated with low birth weight. Moreover, they show that morbidities characteristic of pregnancy (hypertension, preeclampsia, history of preterm, infectious diseases, premature rupture of membranes, and hemorrhages during pregnancy) are also risk factors for low birth weight 1,27 . In fact, infections during pregnancy are also considered risk factors, including asymptomatic bacteriuria ${ }^{28}$, bacterial vaginosis ${ }^{29}$, trichomoniasis ${ }^{30}$, malaria ${ }^{31}$ and maternal periodontal disease ${ }^{32,33}$.

This study has some limitations that must be taken into consideration, one being the fact that the period of eligibility, both for cases and for controls, was 18 years. Within this period, the way in which a number of factors are managed that in this study were shown to be associated with low birth weight evolved considerably. It is probable that differences in the way of recognizing and treating these conditions (for example, preterm labor or maternal morbidities) may affect the magnitude and the significance of the associations reported here. Nevertheless, this is an effect that is very difficult to control when long historical series are being evaluated. In addition, as said previously, the incorrectness of available data on gestational age did not allow for separating cases of low birth weight between preterm and growth restricted newborns. This is a common problem basically for the majority of historical databases of deliveries where an early ultrasound exam is not systematically available for all women.

Another possible limitation of this study refers to the under-notification of some conditions of interest in the records, the non-uniform classification of the degree of severity, and the grouping together of some conditions into larger, heterogeneous categories. Despite these limitations, it is believed that the detection and prenatal management of changeable risk factors such as low maternal BMI, smoking and the interdelivery interval may contribute towards reducing the occurrence of low birth weight. Likewise, adequate prenatal care was found to reduce the occurrence of adverse perinatal events, including low birth weight 14,34 . Therefore, it is feasible to assume that counseling and pre-gestational intervention could possibly contribute similarly to an improvement in perinatal outcome. The same may be said with respect to primary and secondary prevention of maternal morbidity, whether gestational or pre-gestational.

\section{ConcLusion}

Low birth weight represents a condition that results in significant repercussions in healthcare systems, particularly in developing countries. These repercussions, as well as representing a significant neonatal problem, reach far beyond the healthcare field in that they represent high economical costs and affect future generations. Various factors have been identified as being associated with low birth weight; many of them are avoidable. A strategy must now be implemented to alter this outcome and combat what is one more silent epidemic. One possibility for the time being is trying to alert obstetricians for identification of these risk factors in order to possibly take specific interventions that could decrease the occurrence of low birth weight. The demonstration that this really helps and happens would be a good objective for a new ambitious intervention study to be performed in a near future. 


\section{ACKNOWLEDGEMENTS}

We acknowledge the work of all staff members of the Obstetric Unit of the University of Campinas who had been responsible during the last twenty years for feeding the database with information on the deliveries: Anibal Faundes, Angela Bacha, Belmiro G Pereira, Egle C Couto, Eliana Amaral, Fabiana Krupa, Giuliane J Pinto, Helaine M Milanez, Hugo Sabatino, Joao L Pinto e Silva, Jose CG Silva, Magda Mota, Marcelo L Nomura, Maria LB Costa, Mary A Parpinelli, Patricia M Rehder, Renata S Zacaria, Renato Passini Jr., Ricardo Barini, and Roxana Knobel.

\section{Contribution to Authorship:}

All authors were involved in the conception and design of the study; PR Coutinho wrote the first draft of the protocol and JG Cecatti finished it; PR Coutinho, JG Cecatti and JP Souza extracted the information from the general database, performed the initial analysis and planned the strategy for the multivariate analysis; SS Morais performed the statistical analysis; PR Coutinho, FG Surita and JP Souza examined the first results, drafted the tables and gave inputs for discussion; PR Coutinho and JG Cecatti wrote the first draft of the paper; all authors read the draft paper, make comments and suggestions and read and approved the final version of the paper.

\section{Details of ethics approval:}

Research project approved by the IRB of the School of Medical Sciences, University of Campinas on 26 th June 2007 (Number 371/2007).

\section{Conflict of interest: none}

\section{Resumo}

Fatores associados a baixo peso ao nascer em Uma série histórica de partos em Campinas, Brazil

OBJetivo. Identificar os fatores de risco associados com baixo peso ( $<2500 \mathrm{~g})$ ao nascimento.

MÉTodos. Estudo caso-controle não pareado realizado em uma maternidade terciária de Campinas, SP, envolvendo 43.499 nascidos vivos de partos realizados na instituição entre 1986 e 2004. Realizaram-se análises do banco de dados contendo informações sobre os partos de mulheres que deram à luz a crianças de baixo peso (6.477 casos) e peso normal (37.467) ao nascimento. Os fatores associados com o baixo peso ao nascimento foram identificados pelo odds ratio (OR) e IC95\% na análise bivariada e pelo OR ajustado na análise multivariada. Foram estudadas características sócio-demográficas, história reprodutiva, morbidade prévia e fatores relacionados ao pré-natal atual.

RESULTADOS. Os fatores que estiveram associados com o baixo peso ao nascimento foram extremos de idade reprodutiva, baixa escolaridade, baixo peso materno, fumar além do quarto mês de gestação, cesariana anterior, intervalo interpartal $\leq 24$ meses e $\geq 37$ meses, história materna de hipertensão, cardiopatia e parto prematuro, $\leq 5$ consultas de pré-natal e seu início tardiamente na gestação (após o terceiro mês), rotura prematura de membranas, aumento da pressão arterial, doenças infecciosas e hemorragias durante a atual gestação. Obesidade materna e primiparidade foram fatores de proteção.

Conclusão. Estes resultados confirmam os achados de estudos prévios. A detecção e manejo ante-parto de fatores modificáveis, aconselhamento, intervenção pré-concepcional, pré-natal adequado e a implementação de prevenção primária e secundária de morbidade materna devem constituir uma preocupação para todo obstetra como potencial fonte de redução da incidência de baixo peso ao nascimento. [Rev Assoc Med Bras 2009, 55(6): 692 - 9]

Unitermos: Peso ao nascimento. Fatores de risco. Bem-estar materno. Atenção pré-natal.

\section{REFERENCES}

1. World Health Organization. Country, regional and global estimates. Geneva: WHO; 2005.

2. World Health Organization. International statistical classification of diseases and related health problems. 10th revision, version for 2007. Geneva: WHO; 2007. Chapter 16

3. Goldenberg RL, Culhane JF. Low birth weight in the United States. Am J Clin Nutr. 2007;85:584S-90S.

4. Eleftheriades M, Creatsas G, Nicolaides K. Fetal growth restriction and postnatal development. Ann N Y Acad Sci. 2006;1092:319-30.

5. Enkin M, Keirse MJNC, Neilson J, Crowther C, Duley L, Hodnett E, et al. Guide to effective care in pregnancy and childbirth. $3^{\text {rd }}$ ed. Oxford: Oxford University Press; 2000. p.221-5.

6. World Health Organization. The world health report 2005. Make every mother and child count. The greatest risks to life are in its beginning. Geneva: WHO; 2005. p.79-81.

7. Hultman CM, Torrang A, Tuvblad C, Cnattingius S, Larsson JO, Lichtenstein P. Birth weight and attention-deficit/hyperactivity symptoms in childhood and early adolescence: a prospective Swedish twin study. J Am Acad Child Adolesc Psychiatry. 2007;46:370-7.

8. Raqib R, Alam DS, Sarker P, Ahmad SM, Ara G, Yunus M, et al. Low birth weight is associated with altered immune function in rural Bangladeshi children: a birth cohort study. Am J Clin Nutr.2007;85:845-52.

9. Barker DJ. Adult consequences of fetal growth restriction. Clin Obstet Gynecol. 2006;49:270-83.

10. Pfab T, Slowinski T, Godes M, Halle H, Priem F, Hocher B. Low birth weight, a risk factor for cardiovascular diseases in later life, is already associated with elevated fetal glycosylated hemoglobin at birth. Circulation. 2006;114:1687-92.

11. Costello EJ, Worthman C, Erkanli A, Angold A. Prediction from low birth weight to female adolescent depression: a test of competing hypotheses. Arch Gen Psychiatry. 2007;64:338-44.

12. Oral E, Cagdas A, Gezer A, Kaleli S, Aydinli K, Oçer F. Perinatal and maternal outcomes of fetal macrosomia. Eur J Obstet Gynecol Reprod Biol. 2001;99:167-71.

13. Delbaere I, Verstraelen H, Goetgeluk S, Martens G, De Backer G, Temmerman M. Pregnancy outcome in primiparae of advanced maternal age. Eur J Obstet Gynecol Reprod Biol. 2007;135:41-6.

14. Minagawa AT, Biagoline RE, Fujimori E, de Oliveira IM, Moreira AP, Ortega LD. [Low birth weight and maternal conditions in pre-natal.] Rev Esc Enferm USP. 2006:40:548-54.

15. Ehrenberg HM, Dierker L, Milluzzi C, Mercer BM. Low maternal weight, failure to thrive in pregnancy and adverse pregnancy outcomes. Am J Obstet Gynecol. 2003;189:1726-30.

16. Omanwa K, Zimmer M, Tlolka J, Wytrychowska E, Maciejewska J, Drys A. [Is low pre-pregnancy body mass index a risk factor for preterm birth and low neonatal birth weight?] Ginekol Pol. 2006;77:618-23.

17. Kramer MS. Determinants of low birth weight: methodological assessment and meta-analysis. Bull World Health Organ. 1987;65:663-737.

18. Difranza JR, Lew RA. Effect of maternal cigarette smoking on pregnancy complications and sudden infant death syndrome. J Fam Pract 1995;40:385-94.

19. Larsen LG, Clausen HV, Jonsson L. Stereologic examination of placentas from mothers who smoke during pregnancy. Am J ObstetGynecol. 2002;186:531-7.

20. Chiolero A, Bovet P, Paccaud F. Association between maternal smoking and low birth weight in Switzerland: the EDEN study. Swiss Med Wkly. 2005; 135:525-30.

21. Borders AE, Grobman WA, Amsden LB, Holl JL. Chronic stress and low birth weight neonates in a low-income population of women. Obstet Gynecol. 2007;109:331-8.

22. Mohllajee AP, Curtis KM, Morrow B, Marchbanks PA. Pregnancy intention and its relationship to birth and maternal outcomes. Obstet Gynecol. 2007; 109:678-86. 
FACTORS ASSOCIATED WITH LOW BIRTH WEIGHT IN A HISTORICAL SERIES OF DELIVERIES IN CAMPINAS, BRAZIL

23. Murphy CC, Schei B, Myhr TL, Du Mont J. Abuse: a risk factor for low birth weight? A systematic review and meta-analysis. CMAJ. 2001;164:1567-72.

24. Zilberman B. [Influence of short interpregnancy interval on pregnancy outcomes.] Harefuah. 2007;146:42-7.

25. Cecatti JG, Correa-Silva EP, Milanez H, Morais SS, Souza JP. The associations between inter-pregnancy interval and maternal and neonatal outcomes in Brazil. Matern Child Health J. 2008;12:275-81.

26. Graham J, Zhang L, Schwalberg R. Association of maternal chronic disease and negative birth outcomes in a non-Hispanic Black-White Mississippi birth cohort. Public Health Nurs. 2007;24:311-7.

27. Makki AM. Risk factors for low birth weight in Sana'a City, Yemen. Ann Saudi Med. 2002;22:333-5.

28. Herraiz MA, Hernandez A, Asenjo E, Herraiz I. [Urinary tract infection in pregnancy.] Enferm Infecc Microbiol Clin. 2005;23(Suppl 4):40-6.

29. Romanik M, Martirosian G. [Frequency, diagnostic criteria and consequences of bacterial vaginosis in pregnant women.] Przegl Epidemiol. 2004;58:547-53.

30. Wendel KA, Workowski KA. Trichomoniasis: challenges to appropriate management. Clin Infect Dis. 2007;44(S3):S123-9.
31. Guyatt HL, Snow RW. Impact of malaria during pregnancy on low birth weight in sub-Saharan Africa. Clin Microbiol Rev. 2004;17:760-9.

32. Cruz SS, Costa MC, Gomes Filho IS, Vianna MI, Santos CT. [Maternal periodontal disease as a factor associated with low birth weight.] Rev Saude Publica. 2005;39:782-7.

33. Moreu G, Tellez L, Gonzalez-Jaranay M. Relationship between maternal periodontal disease and low-birth-weight pre-term infants. J Clin Periodontol. 2005;32:622-7.

34. Sanchez-Nuncio HR, Perez-Toga G, Perez-Rodriguez P, Vazquez-Nava F. [Impact of the prenatal care in the neonatal morbidity and mortality.] Rev Med Inst Mex Seguro Soc. 2005;43:377-80.

Artigo recebido: 16/08/08 Aceito para publicação: 06/04/09 